\title{
PENGARUH PEMBELAJARAN PENGAJUAN MASALAH BERBANTUAN MEDIA KANCING TERHADAP PENINGKATAN KEMAMPUAN OPERASI HITUNG PECAHAN SISWA KELAS IV SEKOLAH DASAR
}

\author{
Lita Dini Anggraeni Suarlan \\ Mahasiswa Program Pascasarjana, Prodi Pendidikan Dasar, Universitas Negeri Surabaya, \\ e-mail: litadini_466@yahoo.com
}

\section{Received : Juli 2018}

Reviewed: Agustus 2018

Accepted : September 2018

Published : September 2018
ABSTRACT

The research aimed is to describe and analyze: (1) increase the ability of students fractional arithmetic operation, (2) problem posing ability students, (3) students responses, and (4) implementing of teacher in the learning activity, when the learning problem posing by using buttons media on material fractional arithmetic operations in grade 4 elementary school of SD Negeri Telaga Asih 03 Bekasi district. The research was using Quasi Eksperimental design pattern with The Nonequivalent Pretest-Posttest Control Group Design. Data collection techniques were using test and non test techniques. Data obtained through the technique of statistical test were analyzed by Independent T-test trials using aid SPSS 24.0 for Windows. The research result show that: (1) n-gain score fractional arithmetic operation ability of students of two classes gain significancy value 0,000 > 0,05, than the hypothesis of fractional arithmetic operation capability experimental class students who apply problem posing learning by using buttons media better than the fractional arithmetic operation capability control class that implements conventional learning be accepted, (2) the average score of students posttest problem posing ability experimental class students at 14,87 with medium qualifying better than the average score of posttest problem posing ability control class at 10,10 with low qualifications, (3) the percentage of students response to the learning reached $88.27 \%$ categorized as very positive, (4) the percentage of teacher implementing in the learning activity reached $97.1 \%$ with very good categories.Based on data analysis can be concluded that the Problem Posing Learning by Using Buttons Media can improve students fractional arithmetic operations and effectively applied to the material fractional arithmetic operations in the 4th grade of primary school.

Keywords: Problem Posing Learning, Buttons Media, Fractional Arithmetic Operation Capability.

\section{ABSTRAK}

Penelitian ini bertujuan untuk mendeskripsikan dan menganalisis: (1) peningkatan kemampuan operasi hitung pecahan siswa, (2) kemampuan pengajuan masalah siswa, (3) tanggapan siswa, dan (4) aktivitas guru dalam melaksanakan pembelajaran, saat pembelajaran pengajuan masalah berbantuan media kancing pada materi operasi hitung pecahan di kelas IV Sekolah Dasar. Penelitian ini menggunakan pola rancangan Quasi Eksperimental dengan desain penelitian The Nonequivalent Pretest-Posttest Control Group Design. Teknik pengumpulan data menggunakan teknik tes dan non tes. Teknik tes digunakan untuk mengukur peningkatan kemampuan operasi hitung dan kemampuan pengajuan masalah siswa dengan instrumen berupa pretest dan posttest. Teknik non tes digunakan untuk mengetahui tanggapan siswa dengan instrumen berupa angket serta untuk mengetahui aktivitas guru dalam melaksanakan pembelajaran dengan instrumen berupa lembar observasi. Data yang diperoleh melalui teknik tes kemudian dianalisis statistik dengan uji Independent Sample T-test menggunakan bantuan SPSS 24.0 for Windows. Hasil penelitian menunjukkan bahwa: (1) skor n-gain kemampuan operasi 
hitung pecahan siswa dari kedua kelas memperoleh nilai signifkansi $0,000<0,05$, sehingga hipotesis kemampuan operasi hitung pecahan siswa kelas eksperimen yang menerapkan pembelajaran pengajuan masalah berbantuan media kancing lebih baik dibandingkan dengan kemampuan operasi hitung pecahan siswa kelas kontrol yang menerapkan pembelajaran konvensional dapat diterima, (2) rata-rata skor posttest kemampuan pengajuan masalah siswa kelas eksperimen sebesar 14,87 dengan kualifikasi sedang lebih baik dibandingkan dengan rata-rata skor posttest kemampuan pengajuan masalah siswa kelas kontrol sebesar 10,10 dengan kualifikasi rendah, (3) persentase respon siswa terhadap pembelajaran mencapai 88,27\% dengan kategori sangat positif, (4) persentase aktivitas guru dalam melaksanakan pembelajaran mencapai $97,1 \%$ dengan kategori sangat baik. Berdasarkan analisis data dapat disimpulkan bahwa pembelajaran pengajuan masalah berbantuan media kancing dapat meningkatkan kemampuan operasi hitung pecahan siswa dan efektif diterapkan pada materi operasi hitung pecahan di kelas IV Sekolah Dasar.

Kata Kunci: Pembelajaran Pengajuan Masalah, Media Kancing, Kemampuan Operasi Hitung Pecahan.

\section{PENDAHULUAN}

Matematika menjadi bagian integral dari sistem pendidikan nasional. Matematika memegang peranan penting pada proses pengembangan ilmu pengetahuan dan teknologi. Melalui pembelajaran matematika siswa memperoleh latihan baik secara eksplisit maupun secara implisit tentang cara berpikir, terutama dalam memecahkan masalah. Sehingga melalui proses pembelajaran matematika siswa memiliki pandangan yang luas serta memiliki sikap kritis, objektif, terbuka, kreatif dan inovatif. Namun mempelajari matematika tidaklah mudah, siswa selalu menemukan kesulitan dalam mempelajarinya. Russefendi (dalam Mulyadi, 2007: 8) menyatakan "Matematika (ilmu pasti) bagi anak-anak pada umumnya merupakan mata pelajaran yang tidak disenangi, kalau bukan pelajaran yang paling dibenci". Banyak faktor yang menyebabkan hal itu terjadi, salah satu diantaranya ialah bahwasannya materi matematika yang bersifat abstrak dan cenderung tidak menarik sehingga sulit dipahami oleh siswa. Hal ini pada akhirnya mempengaruhi interaksi proses pembelajaran sehingga menyebabkan masih rendahnya kemampuan matematika siswa.

Guru sebagai kunci utama dalam peningkatan mutu pendidikan memiliki kewajiban seperti yang tercantum dalam Undang-undang Guru Nomor 14 Tahun 2005 Pasal 8 disebutkan bahwa "Guru wajib memiliki kualifikasi akademik, kompetensi, sertifikasi pendidik, sehat jasmani dan rohani, serta memiliki kemampuan untuk mewujudkan tujuan pendidikan nasional". Salah satu kewajiban guru disebutkan yaitu memiliki kualifikasi kompetensi profesional. Dari tuntutan undang-undang sekaligus kewajiban ini, guru dituntut mampu menciptakan pembelajaran yang aktif, kreatif dan inovatif sesuai dengan perkembangan dan pertumbuhan peserta didik. Guru harus menciptakan pembelajaran yang melibatkan siswa secara aktif, mendorong mereka untuk melakukan suatu proses melalui berbagai aktivitas yang mendukung pencapaian kompetensi sehingga siswa mendapatkan pengalaman belajar yang bermakna. Salah satu pembelajaran yang dapat melibatkan siswa secara aktif dan memberikan kesempatan siswa untuk bernalar yaitu dengan pembelajaran pengajuan masalah (problem posing).

Melalui pembelajaran pengajuan masalah (problem posing) siswa dibiasakan untuk merumuskan, menghadapi dan menyelesaikan masalah, sehingga siswa dapat menguasai suatu konsep dan memahami suatu masalah dengan lebih baik. Dalam pengajuan masalah siswa diminta untuk membuat pertanyaan dengan penyelesaiannya berdasarkan informasi yang ada. Karena soal dan penyelesaiannya dirancang sendiri oleh siswa, maka dimungkinkan bahwa problem posing dapat mengembangkan kemampuan berpikir peserta didik. Hal ini sejalan dengan hasil penelitian Siswono (1999) menyatakan bahwa terdapat korelasi positif antara kemampuan pengajuan soal dan prestasi belajar siswa.

Selain menciptakan pembelajaran yang aktif, guru juga dituntut untuk menciptakan pembelajaran yang kreatif dan inovatif yang mampu membawa siswa kepada hasil belajar yang optimal. Penggunaan media pembelajaran merupakan salah satu cara inovatif yang dapat digunakan untuk meningkatkan hasil belajar siswa. Penggunaan media terutama pada materi operasi hitung pecahan akan sangat membantu siswa dalam belajar, karena materi ini bersifat abstrak dan cenderung tidak 
menarik sehingga sulit dipahami oleh siswa. Media pembelajaran dapat menjembatani siswa untuk mampu berpikir abstrak. Sudjana (2001) mengemukakan bahwa, media pengajaran dapat mempertinggi proses belajar siswa dalam pengajaran yang pada gilirannya diharapkan dapat mempertinggi hasil belajar yang dicapai. Salah satu media pembelajaran yang dapat dimanfaatkan penggunaannya dalam materi operasi hitung penjumlahan dan pengurangan pecahan ialah media kancing. Kancing merupakan media pembelajaran berupa benda asli atau benda sebenarnya yang penggunaanya hanya dipindahkan dari tempat asalnya.

Berangkat dari masalah tersebut melalui pemikiran dan kajian sementara, peneliti merasa tertarik melakukan penelitian yang lebih mendalam tentang upaya mengatasi permasalahan tersebut, melalui penelitian dengan judul "Pengaruh Pembelajaran Pengajuan Masalah Berbantuan Media Kancing Terhadap Peningkatan Kemampuann Operasi Hitung Pecahan Siswa Kelas IV Sekolah Dasar."

Adapun tujuan dari penelitian ini ialah untuk mendeskripsikan dan menganalisis pengaruh terhadap peningkatan kemampuan operasi hitung pecahan siswa, kemampuan pengajuan masalah siswa, tanggapan siswa, serta aktivitas guru dalam melaksanakan pembelajaran saat pembelajaran pengajuan masalah berbantuan media kancing pada materi operasi hitung penjumlahan dan pengurangan pecahan di kelas IV Sekolah Dasar.

\section{TINJAUAN PUSTAKA}

\section{A. Pengajuan Masalah (Problem Posing)}

\section{Pengertian Pengajuan Masalah}

Pengajuan masalah merupakan kegiatan penting dalam pembelajaran matematika karena pengajuan masalah merupakan dasar pembentukan proses bernalar dan berpikir. Bahkan salah satu pakar matematika NCTM (National Council of Teacher of Mathematics) sangat merekomendasikan agar para siswa diberi kesempatan yang sebesar-besarnya untuk mengalami membuat/mengajukan soal sendiri, NCTM (dalam As'ari,2003: 42). Sedangkan English (dalam Amirulloh,2016: 37) menyatakan bahwa mengajukan masalah dapat mempromosikan semangat inkuiri dan membentuk pikiran yang berkembang dan fleksibel. Pendapat-pendapat tersebut memperlihatkan bahwa pembelajaran pengajuan masalah dapat meningkatkan mutu pembelajaran itu sendiri.

Menurut Silver dan Cai (dalam Siswono,2008: 40), pengajuan masalah diaplikasikan pada tiga bentuk aktivitas kognitif matematika yang berbeda, yaitu :

1) Pengajuan sebelum solusi (presolution posing) Pengajuan sebelum solusi yaitu apabila siswa membuat soal dari situasi yang diadakan.

2) Pengajuan di dalam solusi (within solution posing)

Pengajuan di dalam solusi yaitu apabila siswa merumuskan ulang soal yang berkaitan dengan syarat-syarat pada soal yang telah dipecahkan dalam rangka pencarian alternatif pemecahan soal yang relevan.

3) Pengajuan setelah solusi (postsolution posing) Pengajuan setelah solusi yaitu apabila siswa memodifikasi kondisi soal yang telah diselesaikan untuk membuat soal yang baru dan sejenis agar lebih sederhana dan dapat dikuasai.

Berdasarkan beberapa pendapat diatas maka pengajuan masalah dalam penelitian ini merujuk kepada pengertian pengajuan masalah sebagai suatu tugas kepada siswa unuk membuat soal berdasarkan situasi yang tersedia dan menyelesaikan soal tersebut karena tidak semua siswa dapat menyelesaikan soal-soal yang dibuat, baik secara perseorangan atau secara berkelompok kepada diri sendiri atau pun kepada teman lainnya. Situasi dapat berupa cerita, gambar atau informasi yang berkaitan dengan materi pelajaran.

Dipilihnya pengajuan masalah presolusi sebagai aktifitas kognitif dengan alasan sesuai dengan tingkat perkembangan berpikir siswa yang masih menggunakan tahapan berpikir operasional konkret dimana siswa bebas mengajukan soal berdasarkan situasi problematik yang disediakan guru, dan sesuai dengan tujuan pembelajaran yang ingin dicapai pada materi operasi hitung pecahan di sekolah dasar yang berorientasi untuk menghitung operasi hitung pecahan pada soal, mengajukan soal operasi hitung pecahan dan cara penyelesaiannya, dan menyajikan soal operasi hitung pecahan dengan cara menunjukkan langkah-langkah penyelesaiannya.

\section{Langkah-langkah Pembelajaran Pengajuan Masalah \\ Pembelajaran pengajuan masalah di dalam kelas} akan memberikan beberapa keuntungan. Salah satunya adalah dapat membangkitkan siswa untuk menggali situasi soal dan merumuskan proses inkuiri yang memuaskan secara individu. Suasana ini menciptakan kondisi yang lebih produktif dan menyenangkan.

Langkah-langkah pengajuan masalah yang digunakan dalam penelitian ini adalah langkah-langkah yang telah dirumuskan kembali oleh Siswono (2008: 74) sebagai berikut :

1) Menyampaikan tujuan dan mempersiapkan siswa.

2) Mengorientasikan siswa pada masalah dan mengorganisasikan siswa untuk belajar. 
3) Membimbing penyelesaian secara individual maupun kelompok.

Menyajikan hasil penyelesaian pengajuan diajarkan. Sebab dengan penggunaan media pembelajaran hal-hal yang abstrak dapat dikongkritkan dan hal-hal yang kompleks dapat disederhanakan. Penggunaan media pembelajaran juga dapat membuat kegiatan belajar matematika lebih menarik untuk anak sehingga anak Akan tertarik dan senang dalam mempelajari matematika. Hal tersebut dapat membantu keberhasilan guru dalam melaksanakan pembelajaran matematika dengan optimal. Winarni (1994: 37) memaparkan, media pembelajaran matematika sekolah dasar adalah benda-benda kongkrit yang dapat diamati, diraba, dan digerakan yang digunakan guru untuk menanamkan konsep atau keterampilan matematika pada waktu mengajar.

Media pembelajaran kancing adalah media berupa kancing secara nyata. Kancing termasuk ke dalam golongan media visual non verbal tiga dimensi yang dalam penggunaannya melibatkan indera penglihatan. Kancing merupakan media pembelajaran berupa benda asli (unmodified real thing). Munadi (2013: 108) menjelaskan, unmodified real thing adalah benda yang sebenarnya; sebagaimana adanya, tanpa perubahan, kecuali hanya dipindahkan dari tempat aslinya. Benda seperti ini memiliki ciri seperti dapat digunakan, dalam ukuran yang normal, serta dapat dikenal dengan nama sebenarnya.

1) Pada penelitian ini menggunakan satu set media kancing yang melambangkan nilai suatu pecahan tertentu terdiri atas dua warna kancing yang berbeda yaitu merah dan putih, kancing warna merah melambangkan pembilang dari suatu pecahan sedangkan kancing warna putih untuk membedakan bagian yang bukan merupakan pembilang. Sedangkan penyebut dari suatu pecahan merupakan masalah.

2) Memeriksa pemahaman siswa dan memberikan umpan balik sebagai evaluasi.

\section{Kelebihan Pembelajaran Pengajuan Masalah}

Menurut pendapat para ahli pengajuan masalah memiliki beberapa kelebihan diantaranya adalah:

1) Membantu siswa dalam mengembangkan keyakinan dan kesukaan terhadap matematika, sebab ide-ide matematika siswa dicobakan untuk memahami masalah yang sedang dikerjakan dan dapat meningkatkan performanya dalam pemecahan masalah (English, dalam Siswono, 2008: 40).

2) Mempunyai pengaruh positif terhadap kemampuan memecahkan masalah dan sikap siswa terhadap

matematika

(Silver\&Cai,1996: 529);

3) Membantu siswa untuk mengembangkan kemampuan mengklasifikasikan masalah matematika (Christou,2005: 151);

4) Memberi kesempatan pada siswa untuk mencapai pemahaman yang lebih luas dan menganalisis secara lebih mendalam tentang suatu topik dan konsep-konsep yang diajarkan di kelas (Siswono,1999: 24);

Secara prakteknya pembelajaran pengajuan masalah dapat membangkitkan siswa untuk menggali situasi soal dan merumuskan proses inkuiri yang memuaskan secara individu, sehingga menciptakan kondisi belajar yang lebih produktif dan menyenangkan.

\section{Kekurangan Pembelajaran Pengajuan Masalah}

Selain kelebihan-kelebihan tersebut, pembelajaran pengajuan masalah juga memiliki beberapa kekurangan diantaranya ialah:

1) Membutuhkan lebih banyak waktu bagi siswa untuk menyelesaikan tugas, dan bagi pengajar untuk mengoreksi tugas siswa (Pattahuddin,dalam Siswono, 1999: 24).

2) Siswa acap kali melakukan penipuan, siswa hanya meniru atau menyalin hasil pekerjaan temannya, tanpa mengalami peristiwa belajar (Pattahuddin,dalam Siswono, 1999: 24).

3) Memerlukan keahlian khusus dan kemampuan guru dalam mengarahkan siswa membuat soal, sebab soal yang dibuat siswa dapat beragam (Siswono,1999: 103).

\section{B. MEDIA PEMBELAJARAN KANCING}

Tidak sedikit anak yang daya penalarannya kurang dan sukar membayangkan konsep-konsep yang bersifat abstrak. Oleh karena itu media pembelajaran sangat diperlukan untuk membantu anak dalam memahami konsep yang jumlah dari kancing berwarna merah dan berwarna putih. Media kancing tampak pada gambar berikut:

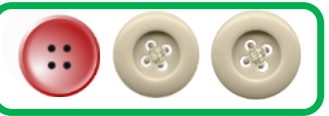

Himpunan di atas melambangkan pecahan $\frac{1}{3}$

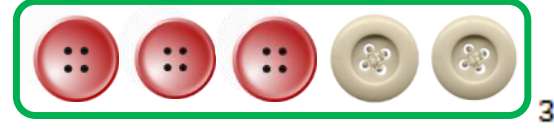

Himpunan di atas melambangkan pecahan $\frac{3}{5}$

Gambar 1. Media Kancing Pecahan

\section{METODE}

Desain yang digunakan pada penelitian ini adalah The Nonequivalent Pretest-Posttest Control Group 
Design, dimana sampel pada kelompok eksperimen dan kontrol tidak dipilih secara random. Desain pretestposttest yang tidak equivalent biasanya dipakai pada eksperimen yang menggunakan kelas-kelas yang sudah ada sebagai kelompoknya (Darmadi,2011: 202). Kelas pertama sebagai kelas eksperimen dan kelas kedua sebagai kelas kontrol. Kedua kelas diberi tes awal (pretest) yang sama. Kelas eksperimen adalah kelas yang diberikan perlakuan berupa pembelajaraan pengajuan masalah berbantuan media kancing, sedangkan kelas kontrol menerapkan pembelajaran yang biasanya dilakukan pada saat pembelajaran dengan menggunakan metode ceramah (pembelajaran konvensional). Setelah beberapa saat, kedua kelas dites dengan tes yang sama sebagai tes akhir (posttest). Hasil pretest dan posttest pada masing-masing kelas dibandingkan (diuji perbedaannya). Perbedaan nilai $n$-gain pada kedua kelas menunjukkan pengaruh pemberian perlakuan terhadap peningkatan hasil perlakuan yang diberikan. Desain yang digunakan pada penelitian ini dapat diilustrasikan pada tabel di bawah ini :

\begin{tabular}{|ll|}
\hline $\mathrm{O}_{1} \times \mathrm{O}_{2}$ \\
\hline $\mathrm{O}_{3}$ & $\mathrm{O}_{4}$ \\
\hline
\end{tabular}

(Sugiyono, 2015: 118)

Keterangan:

$\mathrm{O}_{1}$ : hasil pretest kelas eksperimen

$\mathrm{O}_{2}$ : hasil posttest kelas eksperimen

$\mathrm{O}_{\mathrm{a}}$ : hasil pretest kelas kontrol

$\mathrm{O}_{4}$ : hasil posttest kelas kontrol

$\times$ : perlakuan

Lokasi penelitian ini adalah di SD Negeri Telaga Asih 03 di Kecamatan Cikarang Barat Kabupaten Bekasi. Pada penelitian ini yang menjadi populasi adalah siswa kelas IV SD Negeri Telaga Asih 03 yang terdiri dari 26 siswa kelas IVA dan 26 siswa kelas IVB. Sedangkan yang menjadi sampel penelitiannya yaitu seluruh siswa kelas IV di SD Negeri Telaga Asih 03.

Teknik pengumpulan data yang digunakan dalam penelitian ini adalah teknik tes dan non tes. Teknik tes digunakan untuk mengukur peningkatan kemampuan operasi hitung pecahan dan kemampuan pengajuan masalah siswa dengan instrumen berupa lembar pretest dan posttest. Sedangkan teknik non tes digunakan untuk mengetahui tanggapan siswa dengan instrumen berupa angket serta untuk mengetahui aktivitas guru dalam melaksanakan pembelajaran dengan instruemen berupa lembar pengamatan. Data yang diperoleh melalui teknik tes kemudian dianalisis statistik dengan Uji Independent Sample $t$ test menggunakan bantuan SPSS 24.0 for windows. Dari tes tersebut, maka akan diperoleh skor pretest-posttest dari kedua kelompok yang kemudian akan dibandingkan sehingga diketahui bagaimana pengaruh perlakuan yang diterapkan pada kelompok eksperimen terhadap kemampuan operasi hitung pecahan siswa.

Teknik analisis data dimulai dari teknik validitas butir soal yaitu suatu ukuran yang menunjukkan tingkattingkat kevalidan atau kesahihan suatu instrumen. Suatu instrumen yang valid akan mempunyai validitas tinggi dan sebaliknya instrumen yang kurang valid berarti memiliki validitas rendah. Untuk mengetahui koefisien validitas tes, dalam penelitian ini menggunakan rumus korelasi produk momen memakai angka kasar (raw score), yaitu:

$$
\mathrm{r}_{\mathrm{XY}}=\frac{\mathrm{n} \sum_{\mathrm{i}=1}^{\mathrm{n}} x_{\mathrm{i}} Y_{\mathrm{i}}-\left(\sum_{\mathrm{i}=1}^{\mathrm{n}} x_{\mathrm{i}}\right)\left(\sum_{\mathrm{i}=1}^{\mathrm{n}} Y_{\mathrm{i}}\right)}{\sqrt{\left\{\mathrm{n} \sum_{\mathrm{i}=1}^{\mathrm{n}} x_{\mathrm{i}}{ }^{2}-\left(\sum_{\mathrm{i}=1}^{\mathrm{n}} x_{\mathrm{i}}\right)^{2}\right\}} \cdot \sqrt{\left\{\mathrm{n} \sum_{\mathrm{i}=1}^{\mathrm{n}} Y_{\mathrm{i}}^{\mathrm{n}}-\left(\sum_{\mathrm{i}=1}^{\mathrm{n}} Y_{\mathrm{i}}\right)^{2}\right\}}}
$$

(Furqon, 2004: 103)

Keterangan :

$\mathrm{r}_{\mathrm{XY}}$ :Koefisien korelasi (koefisien validitas)

n :banyak subjek

$\mathrm{X}_{\mathrm{i}} \quad$ :skor butir soal pernyataan/pertanyaan

$\mathrm{Y}_{\mathrm{i}}$ :total skor

Kaidah keputusan uji validitas dalam penelitian ini yaitu jika $r_{\text {hitung }}>r_{\text {tabel }}$ pada taraf signifikansi $5 \%$ berarti butir soal tersebut valid, dan jika $r_{\text {hitung }}<r_{\text {tabel }}$ pada taraf signifikansi $5 \%$ berarti butir soal tersebut tidak valid.

Uji data selanjutnya yaitu uji reliabilitas, pengujian ini menunjukkan suatu instrumen cukup dapat dipercaya atau tidak untuk digunakan sebagai alat pengumpulan data penelitian. Pada penelitian ini menggunakan instrumen tes berupa tes uraian, sehingga cara mencari reliabilitas instrumen yang skornya merupakan rentangan antara beberapa nilai atau yang berbentuk skala yang dalam penelitian ini menggunakan skala 1-4, menggunakan Rumus Alpha sebagai berikut:

$$
\mathrm{r}_{11}=\left(\frac{k}{(k-1)}\right)\left(1-\frac{\sum_{b=1}^{n} \sigma_{b}^{2}}{\sigma^{2} t}\right)
$$

(Sugiyono, 2012: 365)

Keterangan:

$\mathrm{r}_{11}:$ Reliabilitas tes secara keseluruhan

$\mathrm{K}$ : banyak butir soal (item)

$\Sigma \sigma_{b}^{2}:$ jumlah varians butir

$\sigma_{t}^{2} \quad$ : varians total

Jika $r_{11}>r_{\text {tabel }}$ pada taraf signifikansi $5 \%$ berarti soal tersebut reliabel, dan jika $r_{11}<r_{\text {tabel }}$ pada taraf signifikansi $5 \%$ berarti soal tersebut tidak reliabel.

Analisis data selanjutnya adalah dengan menghitung skor $n$-gain kemampuan hitung operasi 
hitung pecahan dari kedua kelas. Analisis data $n$-gain digunakan untuk melihat peningkatan kemampuan operasi hitung siswa setelah diberikan perlakuan. Hal ini dapat dilakukan dengan menggunakan rumus uji ngain sebagai berikut :

$$
\text { n-gain }=\frac{\text { Skor Posttest }- \text { Skor Pretest }}{\text { Skor Maksimum }- \text { Skor Pretest }}
$$

Data n-gain siswa kelas kontrol dan kelas eksperimen tersebut kemudian di uji normalitas dan homogenitasnya sebagai syarat untuk dilakukan pengujian hipotesis perbedaan dua rata-rata n-gain dari kedua kelas.

Uji normalitas dilakukan untuk mengetahui distribusi data dari hasil penelitian normal atau tidak. Uji yang digunakan adalah uji chi kuadrat. Rumus yang digunakan yaitu :

$$
X^{2}=\sum_{i=1}^{k} \frac{\left(f_{i}-f_{e}\right)^{2}}{f_{e}}
$$

(Sugiyono, 2012: 107)

Keterangan:

$\mathrm{X}^{2}$ : Chi Kuadrat yang dicari

$f_{i}$ : frekuensi dari hasil pengamatan

$f_{\text {o }}$ : frekuensi yang harapan

Dengan membandingkan $x^{2}$ hitung dengan nilai $x^{2}$ tabel untuk $\alpha=0,05$ dan derajat kebebasan $(\mathrm{dk})=\mathrm{k}$ -1 , dan kriteria pengujian sebagai berikut :

Bila $x^{2}$ hitung $\geq x^{2}$ tabel , distribusi data tidak normal Bila $x^{2}$ hitung $<x^{2}$ tabel , distribusi data normal

Karena pengujian hipotesis dilakukan dengan menggunakan rumusan statistik uji kesamaan dua ratarata uji dua pihak, maka untuk uji statistik ini diperlukan pengujian homogenitas kedua varians kelas sampel. Untuk uji homogenitas kedua varians kelas sampel ini menggunakan Uji F sebagai berikut:

$$
\mathrm{F}=\frac{S_{1}^{2}}{S_{2}^{2}} \quad \text { dengan } \quad \mathrm{S}=\frac{\sum_{\mathrm{i}=1}^{\mathrm{n}}\left(x_{\mathrm{i}}-\bar{x}\right)^{\mathrm{z}}}{\mathrm{n}-1}
$$

(Furqon, 2004: 62)

Keterangan:

$$
\begin{array}{llll}
\mathrm{S} & : \text { Simpangan baku } & & \\
X_{\mathrm{i}} & : & & \\
\overline{\mathrm{X}} & : & \text { rata-rata n-gain siswa } \\
\mathrm{n} & : \text { jumlah siswa } & & \\
& \text { Dengan kriteria uji adalah terima } \\
H_{0} & \text { jika } F_{\text {hitung }}<F_{\text {tabel }} \text { pada taraf nyata } 5 \% .
\end{array}
$$

Selanjutnya pengujian hipotesis penelitian dengan menggunakan uji perbedaan dua rata-rata dari skor n-gain kedua kelas. Dengan asumsi bahwa data skor n-gain kdua kelas berdistribusi normal dan bersifat homogen, maka yang dipakai adalah uji perbedaan dua rata-rata dengan menggunakan Uji Independent Sample $T$ test dengan rumus sebagai berikut:

$$
\begin{gathered}
\mathrm{t}_{\text {hitung }}=\frac{\overline{\mathrm{x}}_{1-} \overline{\mathrm{x}}_{2}}{s_{g} \sqrt{\frac{1}{\mathrm{n}_{1}}+\frac{1}{\mathrm{n}_{2}}}} \\
\text { dengan, } \\
S_{g}{ }^{2}=\frac{\left(\mathrm{n}_{1}-1\right) \mathrm{s}_{1}{ }^{2}+\left(\mathrm{n}_{2}-1\right) \mathrm{s}_{2}{ }^{2}}{\mathrm{n}_{1}+\mathrm{n}_{2}-2}
\end{gathered}
$$

Keterangan:

$\overline{\mathrm{X}}_{1}$ : Rata-rata n-gain kemampuan operasi hitung pada kelas eksperimen.

$\bar{X}_{2}$ : Rata-rata n-gain kemampuan operasi hitung pada kelas kontrol.

$\mathrm{S}_{\mathrm{g}}$ : Simpangan baku gabungan

$\mathrm{n}_{1}:$ jumlah siswa pada kelas eksperimen

$\mathrm{n}_{2}$ : jumlah siswa pada kelas kontrol

$\mathrm{S}_{1}$ : Simapangan baku n-gain pada kelas eksperimen

$S_{2}$ : Simpangan baku n-gain pada kelas kontrol

Dengan kriteria pengujian adalah terima $H_{0}$ jika

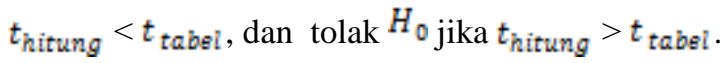

\section{HASIL DAN PEMBAHASAN}

\section{A. Hasil Analisis Statistik}

Pada penelitian ini peneliti menggunakan soal yang sama yang digunakan untuk kegiatan pretest dan posttest. Soal pretest dan posttest ini terdiri dari 7 soal uraian, dimana 5 soal uraian digunakan untuk mengukur kemampuan operasi hitung pecahan siswa sedangkan 2 soal uraian lainnya digunakan untuk mengukur kemampuan pengajuan masalah siswa.Soal pretest dan posttest yang telah divalidasi oleh pakar dan direvisi oleh peneliti kemudian diujicobakan pada siswa yang identik dengan subjek penelitian yang pernah mempelajari materi yang diujikan untuk melihat validitas dan reliabilitas butir soal. Untuk mengetahui validitas soal pretest dan posttest menggunakan rumus korelasi Pearson Product Moment sedangkan untuk mengetahui derajat reliabilitas soal peneliti menggunakan teknik Cronbach's Alpha dengan bantuan program SPSS 24.0. Hasil validitas dan reliabilitas butir soal dari data hasil uji coba sebagai berikut:

1. Hasil Validitas dan Reliabilitas butir soal pretestposttest kemampuan operasi hitung pecahan.

Tabel 1.Validitas dan Reliabilitas Soal Pretest-Posttest Kemampuan Operasi Hitung Pecahan

\begin{tabular}{ccccc}
\hline $\begin{array}{c}\text { Nomor } \\
\text { Butir } \\
\text { Soal }\end{array}$ & $\begin{array}{c}\text { Validitas Butir Soal } \\
\text { Koefisisen } \\
\text { Validitas }\end{array}$ & $\begin{array}{c}\text { Tingkat } \\
\text { Validitas }\end{array}$ & $\begin{array}{c}\text { Reliabilitas Soal } \\
\text { Koefisien }\end{array}$ & $\begin{array}{c}\text { Derajat } \\
\text { Reliabilitas }\end{array}$ \\
$\begin{array}{c}\text { Reliabilitas } \\
1\end{array}$ & 0,810 & Tinggi & & \\
2 & 0,854 & Tinggi & 0,794 & Tinggi \\
3 & 0,763 & Tinggi & & \\
4 & 0,817 & Tinggi & &
\end{tabular}




\section{$5 \quad 0,497 \quad$ Cukup}

Berdasarkan informasi tersebut bahwa soal

Pretest dan Posttest kemampuan operasi hitung pecahan yang telah dikembangkan tersebut memiliki derajat reliabilitas yang tinggi $\left(r_{11}=0,794\right)$ dan semua butir soal valid $\left(r_{X Y} \geq 0,337\right)$.

2. Hasil Validitas dan Reliabilitas butir soal pretestposttest kemampuan pengajuan masalah.

Tabel 2. Validitas dan Reliabilitas Soal Pretest-Posttest Kemampuan Pengajuan Masalah

\begin{tabular}{|c|c|c|c|c|}
\hline \multirow{2}{*}{$\begin{array}{c}\text { Nomor } \\
\text { Butir } \\
\text { Soal }\end{array}$} & \multicolumn{2}{|c|}{ Validitas Butir Soal } & \multicolumn{2}{|c|}{ Reliabilitas Soal } \\
\hline & $\begin{array}{c}\text { Koefisisen } \\
\text { Validitas }\end{array}$ & $\begin{array}{c}\text { Tingkat } \\
\text { Validitas }\end{array}$ & $\begin{array}{c}\text { Koefisien } \\
\text { Reliabilitas }\end{array}$ & $\begin{array}{c}\text { Derajat } \\
\text { Reliabilitas }\end{array}$ \\
\hline 6 & 0,933 & $\begin{array}{l}\text { Sangat } \\
\text { tinggi }\end{array}$ & 0912 & Sangat tingoi \\
\hline 7 & 0,949 & $\begin{array}{l}\text { Sangat } \\
\text { tinggi }\end{array}$ & 0,912 & Sangat tingg1 \\
\hline
\end{tabular}

Berdasarkan informasi tersebut bahwa soal Pretest dan Posttest kemampuan pengajuan masalah yang telah dikembangkan tersebut memiliki derajat reliabilitas yang sangat tinggi $\left(r_{11}=0,912\right)$ dan semua butir soal valid ( $\left.r_{X Y} \geq 0,337\right)$.

Berdasarkan hasil uji coba dan validasi pakar sebelumnya, dapat disimpulkan bahwa soal pretest dan posttest yang telah dikembangkan peneliti layak untuk diimplementasikan dalam kegiatan pembelajaran pengajuan masalah berbantuan media kancing pada materi operasi hitung penjumlahan dan pengurangan pecahan di kelas IV Sekolah Dasar.

Analisis statistik selanjutnya dilakukan terhadap skor peningkatan kemampuan operasi hitung pecahan siswa (n-gain score) yang diperoleh dari data skor pretest dan posttest siswa kedua kelas dengan menggunakan rumus n-gain. Dari data skor n-gain tersebut diketahui bahwa skor $n$-gain siswa kelas kelas eksperimen dengan kriteria rendah sebanyak 4 orang $(15,38 \%)$, kriteria sedang 14 orang $(53,85 \%)$ dan kriteria tinggi 8 orang $(30,77 \%)$ dengan rata-rata skor $n$ gain sebesar 0,54 yang berkriteria sedang. Sedangkan skor $n$-gain siswa kelas kontrol dengan kriteria rendah sebanyak 17 orang $(65,38 \%)$ dan yang memperoleh kriteria sedang sebanyak 9 orang $(34,62 \%)$ dengan ratarata skor $n$-gain sebesar 0,23 yang berkriteria rendah. Data skor $n$-gain kemampuan operasi hitung pecahan siswa selanjutnya digunakan untuk melakukan uji hipotesis dalam penelitian ini. Sebelum pengujian hipotesis dilakukan, maka terlebih dahulu dilakukan pengujian normalitas dan homogenitas data. Dengan bantuan SPSS 24.0, diperoleh ringkasan hasil uji normalitas dan uji homogenitas data skor n-gain kemampuan operasi hitung pecahan siswa sebagai berikut:
Tabel 3. Hasil Uji Normalitas skor $n$-gain Kemampuan Operasi Hitung Pecahan

Kolmogorov-

$$
\text { Smirnov }{ }^{\mathrm{a}} \quad \text { Shapiro-Wilk }
$$

n-gain

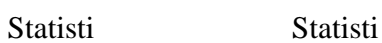

$\begin{array}{lllllll}\text { kontrol } & , 110 & 26 & 200 * & , 965 & 26 & , 491\end{array}$

\begin{tabular}{lllllll} 
eksperimen &, 099 & 26 &, $200 *$ &, 973 & 26 &, 713 \\
\hline
\end{tabular}

Berdasarkan output di atas, diketahui bahwa nilai signifikansi skor n-gain kelas kontrol sebesar 0,200 dan nilai signifikansi skor n-gain kelas eksperimen sebesar 0,200. Berdasarkan nilai signifikansi yang diperoleh tersebut maka dapat disimpulkan bahwa data skor n-gain kedua kelas berdistribusi normal, karena nilai signifikansi kedua kelas lebih besar dari 0,05.

Tabel 4. Hasil Uji Homogenitas skor n-gain Kemampuan Operasi Hitung Pecahan

\begin{tabular}{llrrrr}
\hline & & & & & \\
n-gain & Bevene & & & \\
Statistic & df1 & df2 & Sig. \\
kemampua & Based on Median & 1,401 & 1 & 50 &, 242 \\
$\begin{array}{l}\text { n operasi } \\
\text { hitung }\end{array}$ & $\begin{array}{l}\text { Based on Median and } \\
\text { with adjusted df }\end{array}$ & 1,324 & 1 & 50 &, 255 \\
& $\begin{array}{l}\text { Based on trimmed } \\
\text { mean }\end{array}$ & 1,390 & 1 & 50 &, 244 \\
& & & & & \\
\hline
\end{tabular}

Berdasarkan hasil output di atas diketahui bahwa nilai signifikansi 0,242 >0,05, maka dapat disimpulkan bahwa $n$-gain kemampuan operasi hitung pecahan siswa antara kelas kontrol dengan kelas eksperimen variannya adalah sama ini berarti bahwa data berasal dari populasi yang homogen.

Pada pengujian hipotesis penelitian menggunakan analisis data Independent sample t-test, analisis ini dapat digunakan karena uji prasyarat berupa uji normalitas dan uji homogenitas mendapati bahwa data skor n-gain kemampuan operasi hitung siswa dari kedua kelas normal serta memiliki varian yang sama. Uji Independent sample t-test digunakan untuk mengukur apakah ada perbedaan peningkatan kemampuan operasi hitung pecahan siswa antara kelompok kontrol dan kelompok eksperimen. Untuk uji Independent sample ttest ini pun menggunakan bantuan SPSS 24.0. Dasar pengambilan keputusan dalam uji Independent sample $t$ test adalah:

Jika nilai signifikansi $<0,05$, maka tolak $\mathrm{H}_{0}$ Jika nilai signifikansi $>0,05$, maka terima $\mathrm{H}_{0}$

Berdasarkan analisis data, maka diperoleh suatu hasil seperti tersaji dalam tabel berikut ini: 
Tabel 5. Hasil Uji Independent Sample T test skor n-gain Kemampuan Operasi Hitung Pecahan

\begin{tabular}{|c|c|c|c|c|c|c|c|c|c|c|}
\hline \multirow{5}{*}{$\begin{array}{c}\text { n-gain } \\
\text { kemampu } \\
\text { an } \\
\text { operasi } \\
\text { hitung }\end{array}$} & \multirow{5}{*}{$\begin{array}{c}\text { Equal } \\
\text { variances } \\
\text { assumed } \\
\text { Equal } \\
\text { variances not } \\
\text { assumed }\end{array}$} & \multicolumn{4}{|c|}{$\begin{array}{c}\text { Levene's Test } \\
\text { for Equality of } \\
\text { Variances }\end{array}$} & \multicolumn{3}{|c|}{ t-test for Equality of Means } & \multirow{2}{*}{\multicolumn{2}{|c|}{$\begin{array}{l}95 \% \text { Confidence } \\
\text { Interval of the } \\
\text { Difference }\end{array}$}} \\
\hline & & & & & & $\begin{array}{l}\text { Sig. } \\
(2-\end{array}$ & $\begin{array}{c}\text { Mean } \\
\text { Differen }\end{array}$ & $\begin{array}{c}\text { Std. } \\
\text { Error } \\
\text { Differen }\end{array}$ & & \\
\hline & & $\mathrm{F}$ & Sig. & $\mathrm{T}$ & Df & tailed) & ce & ce & Lower & Upper \\
\hline & & 1,401 & ,242 & $-4,522$ & 50 & ,000 &,- 31154 & ,06889 &,- 44990 &,- 17317 \\
\hline & & & & $-4,522$ & 47,986 & ,000 &,- 31154 & 06889 &,- 45005 &,- 17303 \\
\hline
\end{tabular}

Berdasarkan hasil pengujian hipotesis diperoleh nilai signifikansi Sig (2 tailed) sebesar 0,000. Nilai signifikansi lebih kecil dari 0,05 $(0,000<0,05)$ maka ini berarti H_0 ditolak. Dengan ditolaknya H_0 maka ini berarti bahwa terdapat perbedaan yang signifikan antara rata-rata n-gain kemampuan operasi hitung pecahan siswa kelas kontrol dengan siswa kelas eksperimen. Sehingga dapat disimpulkan bahwa peningkatan kemampuan operasi hitung pecahan siswa kelas eksperimen yang menerapkan pembelajaran pengajuan masalah berbantuan media kancing lebih baik dibandingkan dengan peningkatan kemampuan operasi hitung siswa kelas kontrol yang menerapkan pembelajaran konvensional.

Hal ini juga didukung oleh hasil penelitian (Wahyu, 2013), bahwa penggunaan model problem posing dapat meningkatkan keterampilan operasi hitung pecahan siswa sehingga pembelajaran dengan model problem posing dapat digunakan sebagai salah satu alternatif bagi guru dalam pembelajaran matematika dalam upaya meningkatkan keterampilan operasi hitung pecahan siswa.

\section{B. Hasil Analisis Deskriftif}

\section{Kemampuan Pengjuan Masalah}

Deskripsi kemampuan pengajuan masalah siswa diperoleh melalui analisis deskriftif skor pretest-posttest kemampuan pengajuan masalah. Hasil pretest kemampuan pengajuan masalah siswa kelas eksperimen diperoleh data bahwa terdapat 6 siswa yang berada pada kualifikasi kemampuan pengajuan masalah tingkat tinggi, 3 siswa yang berada pada kualifikasi kemampuan pengajuan masalah tingkat sedang, dan 17 siswa yang berada pada kualifikasi kemampuan pengajuan masalah tingkat rendah. Hal ini menunjukkan bahwa kualifikasi kemampuan pengajuan masalah siswa kelas eksperimen berdasarkan hasil pretest didominasi oleh siswa pada tingkat rendah Berdasarkan hasil analisis diketahui bahwasannya rata-rata skor pretest kemampuan pengajuan masalah siswa kelas eksperimen sebesar 8,32 yang termasuk dalam kualifikasi rendah. Sedangkan hasil pretest kemampuan pengajuan masalah siswa kelas kontrol diperoleh data bahwa terdapat 2 siswa yang berada pada kualifikasi kemampuan pengajuan masalah tingkat tinggi, 2 siswa yang berada pada kualifikasi kemampuan pengajuan masalah tingkat sedang, dan 22 siswa yang berada pada kualifikasi kemampuan pengajuan masalah tingkat rendah. Hal ini menunjukkan bahwa kualifikasi kemampuan pengajuan masalah siswa kelas kontrol berdasarkan hasil pretest didominasi oleh siswa pada tingkat rendah. Berdasarkan hasil analisis diketahui bahwasannya rata-rata skor pretest kemampuan pengajuan masalah siswa kelas kontrol sebesar 7,33 yang termasuk dalam kualifikasi rendah.

Hasil posttest kemampuan pengajuan masalah siswa kelas eksperimen dan diperoleh data bahwa terdapat 12 siswa yang berada pada kualifikasi kemampuan pengajuan masalah tingkat tinggi, 9 siswa yang berada pada kualifikasi kemampuan pengajuan masalah tingkat sedang, dan 5 siswa yang berada pada kualifikasi kemampuan pengajuan masalah tingkat rendah. Hal ini menunjukkan bahwa kualifikasi kemampuan pengajuan masalah siswa kelas eksperimen berdasarkan hasil posttest didominasi oleh siswa pada tingkat tinggi dan sedang. Berdasarkan rata-rata skor kemampuan pengajuan masalah yang berada pada angka 14,87, maka dapat disimpulkan bahwa rata-rata kemampuan pengajuan masalah siswa kelas eksperimen setelah dibeikan pembelajaran pengajuan masalah berbantuan media kancing pada materi operasi hitung pecahan termasuk dalam kualifikasi sedang. Sedangkan hasil posttest kemampuan pengajuan masalah siswa kelas kontrol diperoleh data bahwa terdapat 2 siswa yang berada pada kualifikasi kemampuan pengajuan masalah tingkat tinggi, 5 siswa yang berada pada kualifikasi kemampuan pengajuan masalah tingkat sedang, dan 19 siswa yang berada pada kualifikasi kemampuan pengajuan masalah tingkat rendah. Hal ini menunjukkan bahwa kualifikasi kemampuan pengajuan masalah siswa kelas kontrol berdasarkan hasil posttest didominasi oleh siswa pada tingkat rendah. Berdasarkan rata-rata skor kemampuan pengajuan masalah yang berada pada angka 
10,10, maka dapat disimpulkan bahwa rata-rata kemampuan pengajuan masalah siswa kelas kontrol setelah dibeikan pembelajaran konvensional pada materi operasi hitung pecahan masih termasuk dalam kualifikasi rendah.

Dapat disimpulkan bahwa pembelajaran pengajuan masalah efektif dilihat dari hasil perolehan skor kemampuan pengajuan masalah siswa kelas eksperimen yang mengalami peningkatan. Hal ini juga didukung oleh penelitian (Siswono, 1999) bahwa metode pemberian tugas dengan pengajuan masalah efektif diterapkan karena menunjukkan terdapat hubungan antara kemampuan pengajuan soal dengan prestasi belajar siswa.

\section{Tanggapan Siswa}

Hasil dari penyebaran angket berupa 20 pernyataan tertutup yang diberikan kepada siswa kelas eksperimen memberikan tanggapan positif. Hal ini ditunjukkan dari data hasil analisis tanggapan siswa terhadap pembelajaran pengajuan masalah berbantuan media kancing menunjukkan bahwa persentase tanggapan siswa yang setuju dengan pembelajaran mencapai $88,27 \%$ berbanding dengan $11,73 \%$ siswa yang tidak setuju. Hal ini menunjukkan bahwa tanggapan siswa positif terhadap pembelajaran dan termasuk dalam kategori sangat positif.

Sehingga dapat ditarik kesimpulan bahwa tanggapan siswa terhadap pembelajaran pengajuan masalah berbantuan media kancing pada materi operasi hitung pecahan mendapatkan tanggapan sangat positif. Hal ini juga didukung oleh penelitian (Andayani, 2002) bahwa pembelajaran dengan pengajuan masalah efektif diterapkan karena tanggapan siswa positif terhadap pembelajaran sehingga pembelajaran dengan pengajuan masalah dapat digunakan sebagai salah satu alternatif bagi guru dalam pembelajaran matematika.

\section{Aktivitas Guru Dalam Melaksanakan Pembelajaran Pengajuan Masalah Berbantuan Media Kancing \\ Pengamatan keterlaksanaan pembelajaran pengajuan masalah berbantuan media kancing dilakukan oleh dua orang pengamat. Pengamatan dilakukan menggunakan lembar observasi aktivitas guru pada tiga kali pembelajaran yang dilaksanakan. Berikut hasil pengamatan keterlaksanaan pembelajaran:}

Tabel 6. Hasil Pengamatan Aktivitas Guru

\begin{tabular}{lllllll}
\hline & \multicolumn{5}{l}{ Pembelajaran Pengajuan Masalah Berbantuan Media Kancing } \\
Hasil Pengamatan & \multicolumn{2}{l}{ Pembelajaran 1 } & Pembelajaran 2 & \multicolumn{2}{l}{ Pembelajaran 3 } \\
& P1 & P2 & P1 & P2 & P1 & P2 \\
$\begin{array}{l}\text { Aktivitas guru } \\
\text { dalam mengelola }\end{array}$ & & & & & & \\
$\begin{array}{l}\text { pembelajaran } \\
\text { (keterlaksanaan }\end{array}$ & $94,1 \%$ & $94,1 \%$ & $94,1 \%$ & $100 \%$ & $100 \%$ & $100 \%$ \\
$\begin{array}{l}\text { pembelajaran) } \\
\text { Rata-rata }\end{array}$ & $94,1 \%$ & & & & & \\
\hline
\end{tabular}

Berdasarkan informasi tersebut bahwa aktivitas guru dalam mengelola pembelajaran pengajuan masalah berbantuan media kancing pada pembelajaran 1 adalah $94,1 \%$, pembelajran 2 adalah $97,1 \%$ dan pembelajaran 3 adalah $100 \%$. Secara keseluruhan dapat disimpulkan bahwa aktivitas guru dalam mengelola pembelajaran pengajuan masalah berbantuan media kancing mencapai $97,1 \%$, yang termasuk dalam kategori sangat baik.

Hal ini menunjukkan telah terjadi peningkatan aktivitas guru dalam melaksanakan pembelajaran dari pembelajaran pertama hingga pembelajaran ketiga. Peningkatan aktivitas guru dalam melaksanakan pembelajaran ini menyimpulkan bahwa pembelajaran pengajuan masalah berbantuan kancing praktis dilihat dari aktivitas guru dalam melaksanakan pembelajaran.

Hal ini juga didukung oleh penelitian (Syarbin, 2014) bahwa pembelajaran dengan pengajuan masalah praktis dan efektif diterapkan karena aktivitas guru dalam melaksanakan pembelajaran berkategori baik sehingga pembelajaran dengan pengajuan masalah dapat digunakan sebagai salah satu alternatif bagi guru dalam pembelajaran matematika.

\section{SIMPULAN DAN SARAN}

\section{Simpulan}

Berdasarkan hasil analisis data dan pembahasan hasil penelitian pengaruh pembelajaran pengajuan masalah berbantuan media kancing terhadap peningkatan kemampuan operasi hitung pecahan siswa kelas IV diperoleh beberapa kesimpulan.

Kemampuan operasi hitung pecahan siswa dalam pembelajaran pengajuan masalah berbantuan media kancing mengalami peningkatan yang ditunjukkan dengan rata-rata skor peningkatan kemampuan operasi hitung pecahan sebesar 0,54 yang berkriteria sedang. Peningkatan kemampuan operasi hitung pecahan siswa yang menerapkan 
pembelajaran pengajuan masalah berbantuan media kancing ini lebih besar serta berbeda secara signifikan dengan peningkatan kemampuan operasi hitung siswa yang menerapkan pembelajaran konvensional.

Kemampuan pengajuan masalah siswa pada saat pembelajaran pengajuan masalah berbantuan media kancing pada materi operasi hitung penjumlahan dan pengurangan pecahan memperoleh rata-rata skor posttest sebesar 14,87 dengan kualifikasi sedang.

Tanggapan siswa terhadap penerapan pembelajaran pengajuan masalah berbantuan media kancing pada materi operasi hitung penjumlahan dan pengurangan pecahan mencapai $88,27 \%$ dengan kategori sangat positif.

Aktivitas guru dalam melaksanakan pembelajaran pengajuan masalah berbantuan media kancing pada materi operasi hitung penjumlahan dan pengurangan pecahan mencapai 97,1\% dengan kategori sangat baik.

Berdasarkan beberapa kesimpulan hasil penelitian yang telah diungkapkan di atas, maka dapat disimpulkan bahwa pembelajaran pengajuan masalah berbantuan media kancing berpengaruh lebih baik terhadap peningkatan kemampuan operasi hitung pecahan siswa serta praktis dan efektif diterapkan pada materi operasi hitung penjumlahan dan pengurangan pecahan di kelas IV Sekolah Dasar.

\section{Saran}

Pembelajaran pengajuan masalah berbantuan media kancing dapat menjadi alternatif pembelajaran bagi guru dalam pembelajaran materi operasi hitung penjumlahan dan pengurangan pecahan di kelas IV Sekolah Dasar.

Untuk meningkatkan kemampuan operasi hitung penjumlahan dan pengurangan pecahan siswa, guru kelas IV dapat menggunakan perangkat pembelajaran yang digunakan dalam penelitian ini.

Alokasi waktu pada pembelajaran pengajuan masalah berbantuan media kancing pada materi operasi hitung penjumlahan dan pengurangan pecahan di kelas IV Sekolah Dasar sebaiknya dikelola dengan efektif dan efisien sehingga pembelajaran dapat berjalan dengan baik.

Pembelajaran pengajuan masalah berbantuan media kancing dapat dikembangkan dan diterapkan oleh peneliti lain pada penelitian yang berbeda, misalnya penelitian pengembangan atau penelitian tindakan kelas.

\section{DAFTAR PUSTAKA}

Amirulloh, Muhammad.(2016).Penerapan Pengajuan Masalah (ProblemPosing) Dalam Pembelajaran Operasi Hitung Campuran Untuk Meningkatkan Kemampuan Menyelesaikan Soal Cerita Siswa Kelas IV SDN Daya 1 Makasar.(Tesis Pendidikan
Dasar tidak dipublikasikan).Universitas Negeri Surabaya.

Andayani, R.(2002).Penerapan Penajuan Soal (Problem Posing) dalam Proses Belajar Mengajar Matematika Siswa Kelas III SLTP Negeri 1 Prigen. Surabaya: Tesis Magister Pendidikan tidak dipublikasikan.UNESA

As'ari, A.R.(2003).Pembelajaran Matematika Dengan Pendekatan Problem Posing.Dalam Pelangi Pendidikan Buletin Peningkatan Mutu Pendidikan Menengah Umum.Vol.2 No.2, hal.42-46.

Christou, Constantinos, Mousoulides, Nicholas, Pittalis, Marios, Pitta Pantazi, Demetra, Sriraman, \& Bharath.(2005).An Empirical Taxonomy of Problem Posing Processes.ZDM.Vol 37 No.3, page 149-158.

Darmadi, Hamid.(2011).Metode Penelitian Pendidikan.Bandung: Alfabeta.

Departemen Pendidikan Nasional Indonesia.(2006).Undang-undang guru dan dosen (UU RI No.14 Th 2005). Jakarta : Sinar Grafika

Furqon.(2004).Statistika Terapan

Untuk Penelitian.Bandung: CV Alfabeta.

Mulyadi.(2015, Desember 30). Pentingnya Assesment Portofolio. Received from http://www.jambiekspres.co.id/

Munadi, Yudhi.(2013).Media Pembelajaran.Jakarta: Referensi.

Silver, Edward A \& Cai Jinfa.(1996).An Analysis of Arithmatic Problem Posing by Middle School Students.Jurnal for Research in Mathemathics Education. Vol.27 No.5, November 1996, 521-539.

Siswono, T.Y.E.(1999). Metode Pemberian Tugas Pengajuan Soal (Problem Posing) dalam Pembelajaran Matematika Pokok Bahasan Perbandingan di MTs Negeri Rungkut Surabaya. (Tesis Magister Pendidikan tidak dipublikasikan). Universitas Negeri Surabaya.

Siswono.(2008).Model Pembelajaran Matematika Berbasis Pengjuan dan Pemecahan Masalah untuk Meningkatkan Kemampuan Berfikir Kreatif. Surabaya : Unesa University Pres.

Sudjana, Nana.(2001).Media Pengajaran.Bandung: Sinar Baru Algesindo.

Sugiyono.(2012).Statistika Untuk Penelitian.Bandung: CV Alfabeta.

$\begin{array}{rcrr}\text { Wahyu, } & \text { Riyadi } & \text { dkk.(2013).Penggunaan } & \text { Model } \\ \text { Pembelajaran } & \text { Problem } & \text { Posing } & \text { Untuk } \\ \text { Meningkatkan } & \text { Keterampilan } & \text { Operasi } & \text { Hitung }\end{array}$ 
Pecahan.Jurnal Didaktika Dwija Indria (Solo) Vol.1 No.4.PGSD FKIP Universitas Sebelas Maret Winarni, Endang Setyo.(1994).Media Pembelajaran Matematika Sekolah Dasar. Received from http://abdulhafiz.wordpress.com/. 